\title{
Responsabilidad social y excelencia
}

\author{
Charles Boelen
}

Cuando las universidades pretenden obtener la acreditación como 'campus de excelencia', conviene recordar que tal reconocimiento debería comportar la exhibición plena de su responsabilidad social institucional. En el ámbito de la salud, ello conlleva que los graduados que produce no tan sólo posean las competencias necesarias para mejorar la salud de los ciudadanos y de la sociedad, sino que sean capaces de utilizarlas en el ejercicio de su profesión y rendir cuentas de ello [1].

En las últimas décadas, la calidad de la educación de las profesiones de la salud ha mejorado progresivamente con la introducción de medidas educativas [2], entre las que se pueden destacar: la planificación de los programas por objetivos, el aprendizaje basado en problemas, la formación multidisciplinaria, la inmersión temprana en la comunidad y en la atención primaria, los enfoques centrados en quien aprende, el desarrollo académico del profesorado, la investigación educativa y, recientemente, la introducción de las tecnologías de la información y la comunicación.

Estas innovaciones no han logrado, sin embargo, evitar la crisis global que afecta el desarrollo de los recursos humanos del sector sanitario, y que se manifiesta a través de fenómenos como el déficit cuantitativo de personal, los desequilibrios entre especialistas y necesidades prioritarias de la población, las insuficiencias en la atención primaria, la migración profesional, las carencias en las áreas rurales, el déficit en la prevención de enfermedades y en la promoción de la salud, el escaso compromiso ciudadano con su propia salud y la escasez de incentivos para promover la cooperación con el sector social en aras a obtener un mayor impacto sobre los determi-

\section{Social accountability and excellence}

When universities intend to obtain accreditation as 'campus of excellence', it should be remembered that this type of certification ought to include the obligation to provide full evidence of their institutional social accountability. In the area of health care this means that the graduates they produce should not only possess all of the competencies desirable to improve the health of citizens and society, but should also be able to use them in their professional practice and be held accountable for it [1].

In recent decades the quality of education in the health care professions has improved progressively following the introduction of different educational measures [2], some of the most important of which include objective-based curricular planning, problem-based learning, multidisciplinary training, early immersion in the community and in primary care, learner-focused approaches, academic development of teaching staff, educational research and, more recently, the introduction of the information and communication technologies.

These innovations, however, have not managed to prevent the global crisis that is affecting the development of human resources in the health care sector and which makes itself visible in the form of shortages of staff, imbalances between specialists and the priority concerns of the population, insufficiencies in primary care, professional migration, deficiencies in rural areas, deficits in the prevention of diseases and in health promotion, citizens' scant commitment to their own health, and the lack of incentives to promote cooperation with the social sector in order to make a greater impact on determinants of health. As a result, services are traded at the expense of professional ideals, the administration subsequently no longer
International Consultant in Health Systems and Personnel. Sciez-sur-Léman, Francia.

E-mail

boelen.charles@wanadoo.fr 
nantes de la salud. Esto deriva hacia el mercadeo de los servicios a expensas de los ideales profesionales, la pérdida de confianza en ellos por parte de la administración y la desmotivación de los profesionales de la salud.

¿Cómo afrontar dicha crisis? ¿En qué cuantía las instituciones educativas pueden ayudar a mitigar esta crisis con sus funciones educativa, investigadora y de provisión de servicios? Es imperativo que los programas educativos se relacionen con los planes de salud. En tanto que las políticas sanitarias determinan las competencias que los profesionales deben poseer, las instituciones educativas deben dar una respuesta adecuada.

La Organización Mundial de la Salud (OMS) define la responsabilidad social (accountability) de las facultades de Medicina como 'la obligación de dirigir sus actividades educativas, investigadoras y de servicio a atender las necesidades prioritarias de su comunidad, región y/o nación que les ha conferido el mandato de servir. Las necesidades prioritarias deben ser identificadas conjuntamente por los gobiernos, las organizaciones que prestan los servicios asistenciales de salud, los profesionales sanitarios y el público' [3].

Como marco referencial para la responsabilidad social de las instituciones educativas deben servir los principios humanísticos, relativos a la protección de las personas, y los principios sistémicos, relativos a las relaciones institucionales con el sistema de salud.

Los cuatro principios humanísticos enunciados por la OMS que ilustran el derecho de las personas a la salud son: a) calidad, que persigue la provisión de las mejores medidas de protección, restauración y promoción de bienestar físico, mental y social; b) equidad, que pretende el pleno acceso sin discriminación a los servicios de salud; c) relevancia, que orienta las respuestas a las necesidades prioritarias; y d) efectividad, que hace referencia al uso de los recursos al servicio del interés público con la mayor eficiencia.

Los principios sistémicos aplicables a las instituciones educativas versan sobre el deber de éstas de encontrar la cooperación con los otros agentes sociales (políticos, gestores, profesionales y sociedad civil) implicados en el complejo sistema de salud [4]. Para ser socialmente responsable, una institución educativa debe cuestionarse si sus 'productos' (graduados, modelos de servicio o hallazgos de investigación) son de la mayor utilidad para el interés público. La calificación de 'ex- trusts them, and health care professionals become demotivated.

How must such a crisis be dealt with? To what extent can educational institutions use their educational, research and service functions to help mitigate this crisis? It is essential for educational programmes to be linked to health care plans. As soon as health care policies determine the competencies that professionals must have, educational institutions must act accordingly and provide a suitable answer.

The World Health Organisation (WHO) defines the social accountability of medical schools as 'the obligation to direct their education, research and service activities towards addressing priority health concerns of the community, region and/or nation they have a mandate to serve. The priority health concerns are to be identified jointly by governments, health care organisations, health professionals and the public' [3].

The referential framework for the social accountability of educational institutions must be built on both humanistic principles, concerning the protection of persons, and systemic principles, concerning the relationships between institutions and the health care system.

The four main humanistic principles stated by the WHO that illustrate people's right to health are: a) quality, which seeks to deliver the best measures of protection, restoration and promotion of physical, mental and social well-being; b) equity, which seeks to achieve full access to health care services without any kind of discrimination; c) relevance, which aims to ensure that the most important concerns are tackled first; and d) cost-effectiveness, which refers to making the best use of available resources in delivering a given service to the public.

The systemic principles that are applicable to educational institutions have to do with their duty to seek cooperation with other social agents (policymakers, managers, professionals and civil society) involved in the complex health care system [4]. To be socially accountable, an educational institution must ask itself whether its 'products' (graduates, service models or research findings) are relevant and serve the interests of the public. Only institutions that have an impact on society can be awarded the category of 'excellence'.

It is by questioning its raison dêtre and the ultimate impact of its actions that an institution is taking on a high level of social accountability. This will involve addressing a number of interrelated 
celencia' debe reservarse para designar a las instituciones que tengan un impacto en la sociedad.

Al cuestionarse su razón de ser y el impacto final de su actuación es cuando una institución asume un elevado nivel de responsabilidad social. Para ello es necesario atender a numerosas cuestiones interrelacionadas: la priorización de las necesidades, la promoción de la salud, las características del sistema y las competencias exigibles, los apoyos al desarrollo profesional, el análisis del impacto, etc. Todas estas cuestiones han de considerarse al tratar de establecer la misión institucional. Puesto que por sí solas no pueden llegar a resolverlas, las instituciones educativas deben establecer relaciones con los otros agentes sociales implicados y, también, reconocer que las necesidades se hallan en evolución permanente, lo que demanda un ajuste continuo de los objetivos. Estas relaciones, la recogida de información, los circuitos de retroalimentación y los efectores del cambio necesario demandan que las instituciones reconozcan los principios de la complejidad en sus planes y en sus actuaciones [5]. Las relaciones lineales de causa-efecto deben sustituirse por procesos adaptables en los que se definan los resultados deseables (outputs) y en los que se midan los resultados obtenidos. ¡Esto no es una tarea menor!

La consecución del impacto deseado requiere una definición de los graduados que se desea obtener. Los perfiles competenciales han sido descritos ya por la OMS [6], el General Medical Council británico [7], el Royal Collage of Physicians and Surgeon de Canadá [8] o los promotores del concepto de profesionalismo [9]. Sin embargo, incluso si se consigue producir estos deseables graduados, si sus competencias no son formalmente reconocidas y recompensadas por el sistema, no se conseguirá el impacto deseado y los profesionales quedarán subempleados o se dirigirán a las prácticas que sean incentivadas. Ello indica que las instituciones educativas deben coordinarse con quienes diseñan las políticas sanitarias y con quienes organizan los servicios y emplean a los profesionales. Pero la cooperación sólo será productiva cuando los intereses comunes prevalezcan a los particulares.

En educación médica, al centrarse en la adquisición de la información biomédica y en las habilidades tecnológicas, a menudo se aleja a los estudiantes de las habilidades y actitudes para entender y tratar con los determinantes de la salud. La edu- issues, such as putting needs in order of priority, health promotion, the characteristics of the system and skills that will be required, support for professional development, impact analysis, and so forth. All these matters have to be taken into account when attempting to establish the institutional mission. Since they cannot solve them on their own, educational institutions must establish relationships with the other social agents involved and also recognise the fact that needs are in a permanent state of evolution. As a result, objectives need to be continually adjusted. These relationships, the collection of information, the feedback circuits and those that bring about the necessary change mean that institutions have to acknowledge the principles of complexity in their plans and their actions [5]. The linear cause-effect relationships must be replaced by adaptable processes in which the desirable results (outputs) are defined and in which the results are measured. This is no small task!

Achieving the desired impact requires the prior definition of the graduates that one seeks to obtain. The competency profiles have already been described by the WHO [6], the British General Medical Council [7], the Royal College of Physicians and Surgeons of Canada [8] or the promoters of the concept of professionalism [9]. Nevertheless, even if these desirable graduates are actually produced, if their competencies are not formally recognised and rewarded by the system, the desired impact will not be achieved and the professionals will remain underemployed or they will head towards practices that offer more incentives. This indicates that educational institutions must coordinate with health care policymakers and with those responsible for organising services and employing professionals. But cooperation will only be productive when common interests prevail over individual interests.

Because medical education concentrates on the acquisition of biomedical information and on technological skills, students are often led away from the skills and attitudes needed to understand and deal with determinants of health. Medical education currently focuses on methods of learning rather than on the social purpose and moral obligations of the profession. It insists on processes, but forgets the impact.

The educational revolution that began a century ago with the Flexner report [10] led to the reinforcement of the scientific aspects of the curriculum as a necessary step to actually come into contact with pa- 
cación médica se concentra actualmente en los métodos de aprendizaje y no tanto en el propósito social y las obligaciones morales de la profesión. Insiste en los procesos, pero olvida el impacto.

La revolución educativa iniciada hace un siglo por el informe Flexner [10] llevó a reforzar la naturaleza científica del currículo como paso obligado para acceder al contacto con los pacientes y a su entorno social, y a la incorporación tardía y limitada de las ciencias sociales y de las humanidades, a la autonomía de las disciplinas y los departamentos, a una enseñanza vertical a expensas de una enseñanza integrada, y a la marginalización de la salud pública. La falta de valoración del impacto de los graduados y de las necesidades sociales emergentes han aislado a las instituciones de su entorno. La academia ha perdido un siglo para establecer como su razón de ser el impacto sobre el bienestar social [11].

La actuación de las facultades de Medicina debe basarse en las necesidades sociales identificadas en un proceso con tres dominios interrelacionados: la conceptualización, la producción y la 'utilizabilidad' de los médicos producidos.

El dominio de conceptualización requiere un diseño colaborativo que resuelva la dicotomía entre el tipo de profesional necesario y el sistema que va a utilizar sus habilidades. El dominio de producción contiene los elementos del entrenamiento/aprendizaje y el dominio de 'utilizabilidad' incluye las iniciativas de la institución para que los médicos que ha formado sean utilizados de la mejor manera posible.

Para que las facultades de Medicina apliquen con éxito el modelo de 'conceptualización-producción-utilizabilidad' (CPU) son necesarios mecenazgos sostenidos para construir los circuitos de retroalimentación de las actividades de CPU. Si todos los agentes sociales no comparten los mismos valores, la responsabilidad social no podrá ser cumplimentada por ninguno de ellos.

Desde la instauración de las normas de evaluación y acreditación de las facultades de Medicina estadounidense por el Liaison Comittee on Medical Education [12] y las más recientes de la World Federation of Medical Education [13], el interés por los dominios de la conceptualización y de la 'utilizabilidad' ha sido siempre marginal.

En 1995, la OMS recomendó que los principios de la responsabilidad social fueran garantía de calidad de la educación médica y grupos in- tients and their social milieu. It also resulted in the late and rather limited incorporation of the social sciences and humanities, the autonomy of disciplines and departments, vertical education at the expense of an integrated education, and the marginalisation of public health care. Both failure to value the impact of graduates and the emerging social concerns have isolated institutions from their setting. It has taken the academia a century to establish impact on social well-being as its raison dêtre [11].

Medical schools must act in accordance with the social concerns that can be identified in a process that consists of three interrelated domains: the conceptualisation, the production and the 'usability' of the physicians that are produced.

The conceptualisation domain requires a collaborative design that resolves the dichotomy between the type of professional that is needed and the system that is going to use his or her skills. The production domain contains the training/learning elements and the 'usability' domain includes the initiatives undertaken by the institution so that the doctors it has trained are used in the best possible way.

For medical schools to be able to apply the 'conceptualisation-production-usability' (CPU) model successfully, sustained patronage is needed in order to build the feedback circuits for the CPU activities. If the same values are not shared by all the social agents, then none of them will be able to fulfil social accountability.

Since the standards for assessing and accrediting US medical schools were established by the Liaison Committee on Medical Education [12] and, more recently, by the World Federation of Medical Education [13], only marginal interest has ever been shown in the domains of conceptualisation and 'usability'.

In 1995, the WHO recommended that the principles of social accountability should ensure the quality of medical education, and international groups such as The Network towards Unity and Health [14], the Deans of French-Speaking Medical Schools organisation and the International Francophone Society of Medical Education have begun to lend support to this line of action. Furthermore, analysts of national health policies and the United Nations, through the 'Millennium Development Goals', also endorse such a reorientation [15].

As globalisation reassesses social impact, societies will seek to justify their investments with sounder evidence of their impact on public well-being. 
ternacionales como The Network towards Unity for Health [14], la organización de decanos de facultades de Medicina francófonas y la sociedad internacional francófona de educación médica, han comenzado a dar su apoyo a esta línea de acción. Además, los analistas de las políticas nacionales de salud y las Naciones Unidas, mediante los 'objetivos de desarrollo del milenio', suman su apoyo para tal reorientación [15].

En tanto que la globalización reevalúa el impacto social, las sociedades buscarán justificar sus inversiones con evidencias más sólidas acerca de su impacto sobre el bien público. Las facultades de Medicina deben prepararse para someterse a escrutinio y considerar los argumentos éticos, democráticos, económicos y políticos a favor del modelo de CPU.

\section{Cuestiones éticas: causas y consecuencias}

Minimizar riesgos (en primer lugar: no causar daño) en acciones que puedan afectar a la salud humana es un principio más antiguo que Hipócrates. La sociedad exige este principio de precaución de los profesionales de la salud y, de forma creciente, de las instituciones que los producen. Además, la sociedad exige que se establezca una relación entre las decisiones de actuación y sus efectos a largo plazo. Aunque una relación entre estrategias educativas y la salud poblacional no es fácilmente demostrable, existen para ello aproximaciones indirectas. Es posible diferenciar una institución socialmente responsable de otra que no lo sea $[2,3]$. Es necesario proporcionar evidencias de qué programas educativos de instituciones socialmente responsables dan lugar a profesionales que responden a las necesidades de salud prioritarias de la sociedad.

\section{Cuestiones democráticas: apertura y transparencia}

Las áreas reservadas a los expertos son cada vez más asequibles al público. El amplio acceso a la información y una actitud más crítica de los ciudadanos lleva a cuestionar la gestión de cualquier institución. El reconocimiento explícito de que una institución es socialmente responsable
Medical schools must prepare themselves to be submitted to scrutiny and to consider the ethical, democratic, economic and political arguments in favour of the CPU model.

\section{Ethical issues: causes and consequences}

Minimising the risks (first of all: not causing any harm) when performing actions that can affect the health of human beings is a principle that dates back to before Hippocrates. Society demands this principle of precaution from health care professionals and, increasingly more frequently, from the institutions that produce them. Moreover, society calls for a relationship to be established between the policy decisions and their long-term effects. Although it is not easy to prove the existence of a relationship between educational strategies and the health of the population, this can be achieved by indirect approaches. It is possible to distinguish between an institution that is socially accountable and one that is not $[2,3]$. Evidence must be provided of what educational programmes used at socially accountable institutions give rise to professionals who respond to the priority health concerns of society.

\section{Democratic issues: openness and transparency}

Areas reserved for experts are becoming increasingly more available to the public. Widespread access to information and a more critical attitude in citizens lead the management of any institution to be questioned. One benefit to be gained from the explicit recognition of the fact that an institution is socially accountable will be to raise the level of trust in both its students and the public.

\section{Economic issues: results and support}

Greater transparency will make it easier to compare institutions. Accreditation based on the principles of social accountability will enable the authorities, funding agencies and civil society to provide better-informed support for those institutions with a greater capacity to produce a social impact. 
conllevará el beneficio de conferir confianza tanto a sus estudiantes como al público.

\section{Cuestiones económicas: resultados y apoyos}

Una mayor transparencia facilitará la comparación entre instituciones. La acreditación basada en los principios de la responsabilidad social permitirá a las autoridades, a las agencias financiadoras y a la sociedad civil apoyar con mayor conocimiento de causa a aquellas instituciones con mayor capacidad de producir un impacto social.

\section{Cuestiones políticas: enfoque sistémico y potenciación de sinergias}

El buen gobierno de una institución se define por su capacidad para tener en cuenta la complejidad de su entorno sociopolítico, aprovechándolo para crear mecenazgos cooperativos con otras instituciones con una misión similar o complementaria. Es previsible que las autoridades reconocerán la excelencia y aprovisionarán preferentemente aquellas instituciones con capacidad de crear sinergias que originen mayor coherencia y mejores resultados del sistema de salud.

\section{Conclusión}

Los sistemas de acreditación adecuadamente diseñados son fuerzas poderosas para conseguir el cambio deseable y la mejora de calidad en cualquier sistema complejo. Esto resulta especialmente cierto para las facultades de Medicina. La acreditación facilita la introducción de la garantía de calidad y sirve de guía a las instituciones para su desarrollo. Por lo tanto, es muy importante estar atentos a los acontecimientos en esta área, ya que existe una urgente necesidad de fomentar su adaptación a los principios de la responsabilidad social. Sólo así podrán ser evaluadas correctamente las instituciones educativas y reconocidas por su capacidad real para afrontar las necesidades de salud más urgentes de la población.

\section{Political issues: systemic approach and enhancing synergies}

The extent to which an institution is well governed can be defined by its capacity to take into account the complexity of its socio-political setting and to take advantage of it to create cooperative patronages with other institutions with a similar or complementary mission. Authorities will presumably acknowledge excellence and give priority to supplying institutions with the capacity to create synergies that make the health care system more coherent and allow better results to be produced.

\section{Conclusion}

Suitably designed systems of accreditation are powerful forces with which to accomplish both desirable change and improved quality in any complex system. This is especially true in the case of medical schools. Accreditation facilitates the introduction of quality assurance and serves to guide the development of the institutions. Therefore, it is essential to be pay attention to the events taking place in this area, since there is an urgent need to encourage its adaptation to the principles of social accountability. Only in this way will it be possible to evaluate educational institutions properly and to recognise their real capacity to cope with the most pressing health concerns in the population. 


\section{Bibliografía / References}

1. Boelen C, Woollard B. Social accountability and accreditation: a new frontier for educational institutions. Med Educ 2009; 43: 887-94.

2. Woollard B. Caring for a common future: medical schools social accountability. Med Educ 2006; 40: 301-11.

3. Boelen C, Heck J. Defining and measuring the social accountability of medical schools. Geneva: World Health Organization; 1995.

4. Boelen C. Towards unity for health: challenges and opportunities for partnership in health development. Geneva: World Health Organization; 2000.

5. World Health Organization. Global health workforce alliance: strategic plan. Geneva: WHO; 2006.

6. World Health Organization. Doctors for health: a WHO global strategy for reorienting medical education and medical practice for Health for All. Geneva: WHO; 1996 (WHO/HRH/96.1).

7. General Medical Council. Tomorrow's doctors: recommendations on undergraduate medical education. London: GMC; 2003.

8. Frank JR. ed. The CanMEDS physician competency framework: better physicians better care. Ottawa: Royal College of Physicians and Surgeons of Canada; 2005.
9. American Board of Internal Medicine Foundation, American College of Physicians Foundation \& European Federation of Internal Medicine. Medical professionalism in the new millennium: a physician charter. Ann Int Med 2002; 163: 243-6.

10. Flexner A. Medical education in the United States. A report to the Carnegie Foundation for the advancement of teaching. New York: Carnegie Foundation; 1910.

11. Boelen C. A new paradigm for medical schools a century after Flexner's report. Bull World Health Organ 2002; 80: 592-3.

12. Liaison Committee on Medical Education. Functions and structure of a medical school. Standards for accreditation of medical education programs leading to an MD degree. Washington: LCME; 2008.

13. Karle $\mathrm{H}$. International recognition of basic medical education programs. Med Educ 2008; 42: 12-7.

14. World Health Organization. Network towards Unity for Health. URL: http://www.the-netwoktifh.org. [15.11.2008].

15. United Nations. Millennium development goals. URL: http://www.un.org/milleniumgoals/index.shtml. [15.11.2008]. 